\title{
Ruegeria scottomollicae sp. nov., isolated from a marine electroactive biofilm
}

\author{
Ilse Vandecandelaere, ${ }^{1}$ Olivier Nercessian, ${ }^{2}$ Eveline Segaert, ${ }^{1}$ \\ Wafa Achouak, ${ }^{2}$ Marco Faimali ${ }^{3}$ and Peter Vandamme ${ }^{1}$
}

\author{
Correspondence \\ Ilse Vandecandelaere \\ Ilse.Vandecandelaere@UGent.be
}

\author{
${ }^{1}$ Laboratorium voor Microbiologie, Vakgroep Biochemie, Fysiologie en Microbiologie, Universiteit \\ Gent, K. L. Ledeganckstraat 35, B-9000 Gent, Belgium \\ ${ }^{2}$ LEMiR, Laboratoire d'Ecologie Microbienne de la Rhizosphère, CNRS-CEA-Université de la \\ Méditerranée, DEVM, Dpt Ecophysiologie Végétale et de Microbiologie/DSV CEA Cadarache, \\ 13108 Saint Paul Lez Durance, France \\ ${ }^{3}$ Istituto di Scienze Marine - Consiglio Nazionale delle Ricerche (ISMAR-CNR), Via de Marini 6, \\ 16149 Genoa, Italy
}

\begin{abstract}
Seventy isolates were obtained from a marine electroactive biofilm that was generated on a cathodically polarized stainless steel electrode (Genoa, Italy). The genetic diversity was investigated by means of BOX-PCR fingerprinting and two clusters of isolates with similar BOX-PCR profiles were delineated. Whole-cell fatty acid methyl ester analysis and 16S rRNA gene sequence analysis showed that the isolates belonged to the Roseobacter lineage of the class Alphaproteobacteria. DNA-DNA hybridization experiments and a biochemical analysis demonstrated that four isolates belonged to the species Ruegeria mobilis. However, 66 isolates from the second BOX-PCR cluster constituted a novel species within the genus Ruegeria, for which the name Ruegeria scottomollicae sp. nov. is proposed. The DNA G+C content was $61.0 \pm 0.4 \%$. The type strain is LMG $24367^{\top}$ (=CCUG $55858^{\top}$ ).
\end{abstract}

The genus Ruegeria was created by Uchino et al. (1998) to accommodate the generically misclassified species Agrobacterium atlanticum, Agrobacterium gelatinovorum and Roseobacter algicola, with Ruegeria atlantica as the type species. This genus comprises marine, aerobic, Gram-negative, catalasepositive, oxidase-positive rods. Subsequently, Arahal et al. (2005) reclassified Ruegeria gelatinovorans as Thalassobius gelatinovorus and Martens et al. (2006) restricted the genus Ruegeria to its type species by transferring Ruegeria algicola to the genus Marinovum. More recently, Yi et al. (2007) transferred the two species of the genus Silicibacter [Silicibacter lacuscaerulensis (Petursdottir \& Kristjansson, 1997) and Silicibacter pomeroyi (González et al., 2003)] to the genus Ruegeria; Ruegeria mobilis and Ruegeria pelagia were also described (Lee et al., 2007; Muramatsu et al., 2007). At the time of writing, the genus Ruegeria comprised five recognized species, i.e. Ruegeria atlantica, Ruegeria pomeroyi, Ruegeria lacuscaerulensis, Ruegeria pelagia and Ruegeria mobilis,

The GenBank/EMBL/DDBJ accession numbers for the 16S rRNA gene sequences of strains LMG $24367^{\top}$, LMG 24368, LMG 24371 and LMG 24372 are AM905330, AM905331, AM905332 and AM905333, respectively.

A dendrogram representing the BOX-PCR profiles of the 70 isolates material described in this work is available as supplementary material with the online version of this paper. although the assignation of Ruegeria pomeroyi and Ruegeria lacuscaerulensis is controversial (Muramatsu et al., 2007).

The present taxonomic study was performed in the context of the analysis of the microbial population present in a marine, electroactive biofilm [EA BIOFILMS-508866 (NEST)], generated on a stainless steel cathode that was exposed to natural seawater at the ISMAR-CNR that is located in the port of Genoa, Italy (Faimali et al., 2008; Vandecandelaere et al., 2008). The biofilm was removed from the stainless steel cathode by sonication (Branson 3200 sonicator) for $90 \mathrm{~s}$ in a sterile plastic tube containing $30 \mathrm{ml}$ $0.85 \% \mathrm{NaCl}$ solution. Diluted cell suspensions $\left(10^{-1}\right.$ to $\left.10^{-6}\right)$ were spread onto marine agar 2216 (MA; Difco) for aerobic incubation at $20{ }^{\circ} \mathrm{C}$ for several days. Pure cultures were obtained and the isolates were stored at -20 or $-80{ }^{\circ} \mathrm{C}$ using Microbank vials.

DNA was extracted from the 70 isolates as described by Pitcher et al. (1989) and the genetic diversity was investigated by means of repetitive DNA-PCR fingerprinting using the BOX-A1R primer (5'-CTACGGCAAGGCGACGCTGACG3') (Rademaker et al., 2000; Versalovic et al., 1994). The DNA profiles obtained were analysed numerically using BIONUMERICS 4.61 software (Applied Maths). Two clusters of isolates with similar BOX-PCR profiles were delineated: BOX-PCR cluster 1 , comprising four isolates sharing at least $65.8 \%$ profile similarity; and BOX-PCR cluster 2, 
representing 66 isolates sharing at least $76 \%$ profile similarity (see Supplementary Fig. S1, available in IJSEM Online). A numerical analysis of the BOX-PCR fingerprints of BOXPCR cluster 1 isolates and of a selection of BOX-PCR cluster 2 isolates is shown in Fig. 1. In both BOX-PCR clusters, but especially in BOX-PCR cluster 2, some isolates exhibited almost identical DNA profiles, indicating that they probably originated from the same strain. In contrast, both clusters also comprised isolates with clearly distinguishable profiles, suggesting the presence of multiple strains.

All isolates were examined using whole-cell fatty acid methyl ester analysis (Mergaert et al., 2001) and were tentatively identified as alphaproteobacteria. The dominant fatty acids of the 70 isolates were $\mathrm{C}_{10: 0} 3-\mathrm{OH}(4.9 \pm 1.0 \%)$, 11-methyl $\mathrm{C}_{18: 1} \omega 7 c(3.4 \pm 1.4 \%), \mathrm{C}_{16: 0}(1.8 \pm 0.5 \%), \mathrm{C}_{16: 0} 2-\mathrm{OH}$ $(6.0 \pm 0.8 \%), \mathrm{C}_{18: 1} 2-\mathrm{OH}(3.9 \pm 0.8 \%), \mathrm{C}_{18: 1} \omega 7 c(73.8 \pm$ $2.5 \%$ ) and an unknown fatty acid with an equivalent chain length of $11.799(4.1 \pm 0.8 \%)$. In general, the same types and proportions of fatty acids were present in both BOX-PCR clusters, with the exception of $\mathrm{C}_{12} 3-\mathrm{OH}(1.4 \pm 0.9 \%)$ and $\mathrm{C}_{18: 0}(1.3 \pm 0.6 \%)$, which were only detected in BOX-PCR cluster 1 isolates.

Isolates from both BOX-PCR clusters were selected for $16 \mathrm{~S}$ rRNA gene sequencing on the basis of their BOX-PCR profiles as we looked for the ones with the most different DNA profiles (Fig. 1). Almost-complete 16S rRNA gene sequences (1343-1403 bp) were obtained for representatives of BOX-PCR cluster 1 (LMG 24371 and LMG 24372) and of BOX-PCR cluster 2 (LMG $24367^{\mathrm{T}}$ and LMG 24368) using the universal primers pA $\left(5^{\prime}\right.$-AGAGTTTGATCCTGGCTCAG-3') and pH (5'-AAGGAGGTGATCCAGCCGCA-3') (Edwards et al., 1989), as described previously
(Mergaert et al., 2001). A partial 16S rRNA gene sequence (430 bp) was obtained for a BOX-PCR cluster 1 isolate (R28052) and partial $16 \mathrm{~S}$ rRNA gene sequences ranging from 331 to 414 bp were obtained for six isolates of BOX-PCR cluster 2 (R-28698, R-28710, R-28733, R-28795, R-28799 and R-28807) by using the universal primer $\mathrm{pD}\left(5^{\prime}-\right.$ GTATTACCGCGGCTGCTG-3'), as described by Coenye et al. (1999) (data not shown). The FASTA program was used to search the public databases for the sequences most similar to those of LMG 24371, LMG 24372, LMG $24367^{\mathrm{T}}$ and LMG 24368. These 16S rRNA gene sequences were aligned using CLUSTAL_X (Thompson et al., 1997) and edited using BioEdit (Hall, 1999) and ForCon (Raes \& Van De Peer, 1999). A neighbour-joining dendrogram was constructed (Saitou \& Nei, 1987) using TREECON (Van De Peer \& De Wachter, 1994) (Fig. 2). The tree topology was confirmed by using maximum-parsimony and maximumlikelihood analyses (data not shown).

The 16S rRNA gene sequence similarities between the three representatives of BOX-PCR cluster 1 (LMG 24371, LMG 24372 and R-28052) were high, ranging from 99.2 to $99.9 \%$. These data suggested that BOX-PCR cluster 1 isolates belong to the same species (Stackebrandt \& Ebers, 2006) and confirmed that isolates with very similar BOX-PCR profiles are closely related (Rademaker \& De Bruijn, 1997). The closest phylogenetic neighbours of BOX-PCR cluster 1 isolates were Ruegeria pelagia KCCM $42378^{\mathrm{T}}$ and Ruegeria mobilis CIP $109181^{\mathrm{T}}$, with $99.9-100 \% 16 \mathrm{~S}$ rRNA gene sequence similarity. In contrast, the phylogenetic relationship with respect to the type strains of the other established Ruegeria species (Ruegeria lacuscaerulensis LMG $23162^{\mathrm{T}}$, Ruegeria pomeroyi LMG $23168^{\mathrm{T}}$ and Ruegeria atlantica LMG

Pearson comelation (Opt 0.37\%) [0.0\%-100.0\%]

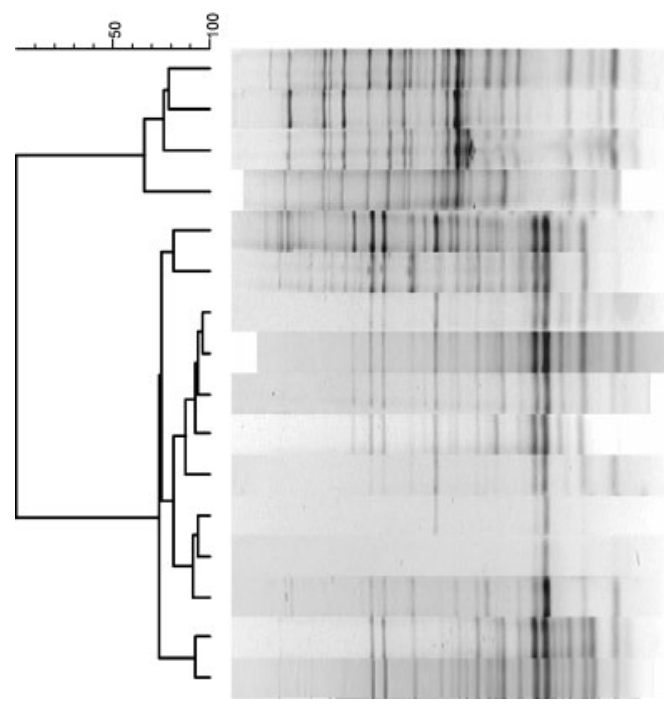

$\begin{array}{lll}\text { R-26185 } & \text { Ruegeria mobilis } & 1 \\ \text { R-28052 } & \text { Ruegeria mobilis } & 1 \\ \text { R-26194 } & \text { Ruegeria mobilis } & 1 \\ \text { R-26189 } & \text { Ruegeria mobilis } & 1 \\ \text { R-28704 } & \text { Ruegeria scottomollicae sp. nov. } & 2 \\ \text { R-28734 } & \text { Ruegeria scottomollicae sp. nov. } & 2 \\ \text { R-28800 } & \text { Ruegeria scottomollicae sp. nov. } & 2 \\ \text { R-28810 } & \text { Ruegeria scottomollicae sp. nov. } & 2 \\ \text { R-28724 } & \text { Ruegeria scottomollicae sp. nov. } & 2 \\ \text { R-28807 } & \text { Ruegeria scottomollicae sp. nov. } & 2 \\ \text { R-28799 } & \text { Ruegeria scottomollicae sp. nov. } & 2 \\ \text { R-28733 } & \text { Ruegeria scottomollicae sp. nov. } & 2 \\ \text { R-28751 } & \text { Ruegeria scottomollicae sp. nov. } & 2 \\ \text { R-28710 } & \text { Ruegeria scottomollicae sp. nov. } & 2 \\ \text { R-28698 } & \text { Ruegeria scottomollicae sp. nov. } & 2 \\ \text { R-28795 } & \text { Ruegeria scottomollicae sp. nov. } & 2 \\ & \end{array}$

LMG 24371

LMG 24372

LMG 24368

LMG 24367'

Fig. 1. Dendrogram representing the BOX-PCR profiles of BOX-PCR cluster 1 isolates and a selection of BOX-PCR cluster 2 isolates. The BOX-PCR profiles were clustered by UPGMA based on the Pearson product-moment correlation coefficient. 


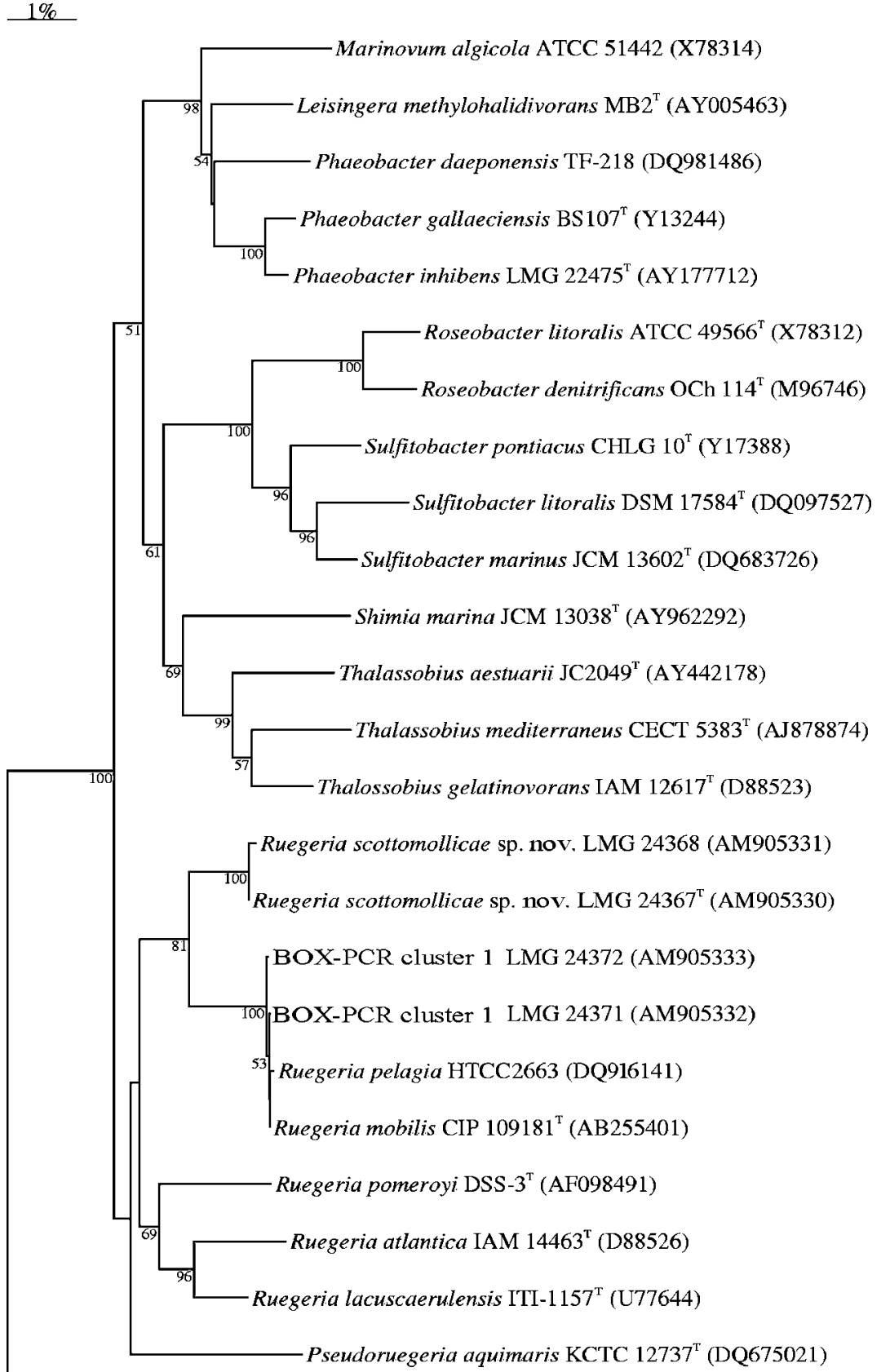

Stappia stellulata IAM $12621^{\mathrm{T}}$ (D88525)
Fig. 2. Neighbour-joining dendrogram depicting the 16S rRNA gene sequences of Ruegeria scottomollicae sp. nov., BOX-PCR cluster 1 isolates and their closest phylogenetic neighbours. Bootstrap percentages (based on 1000 replicates) $>50 \%$ are shown at nodes. Bar, $1 \%$ sequence divergence.
$23161^{\mathrm{T}}$ ) was more distant, as $16 \mathrm{~S}$ rRNA gene sequence similarities of $96.1-96.6 \%$ were detected (Fig. 2).

The eight representatives of BOX-PCR cluster 2 (LMG $24367^{\mathrm{T}}$, LMG 24368, R-28698, R-28710, R-28733, R-28795, R-28799 and R-28807) were also closely related: 16S rRNA gene sequence similarities ranging from 99.7 to $100 \%$ were detected, strongly suggesting that BOX-PCR cluster 2 isolates belong to the same species (Stackebrandt \& Ebers, 2006). The closest phylogenetic neighbours of BOXPCR cluster 2 isolates were Ruegeria mobilis CIP $109181^{\mathrm{T}}$ (97.9-98.1 \% 16S rRNA gene sequence similarity), Ruegeria pelagia KCCM $42378^{\mathrm{T}}$ (97.8-97.9\% sequence similarity) and BOX-PCR cluster 1 isolates (97.8-98.1\% sequence similarity). The $16 \mathrm{~S}$ rRNA gene sequence similarities between representatives of BOX-PCR cluster 2 and the other established Ruegeria species (Ruegeria pomeroyi LMG $23168^{\mathrm{T}}$, Ruegeria lacuscaerulensis LMG $23162^{\mathrm{T}}$ and Ruegeria atlantica LMG $23161^{\mathrm{T}}$ ) were low $(95.8-96.6 \%)$ (Fig. 2).

DNA-DNA hybridizations were performed with BOXPCR cluster 1 strains (LMG 24371 and LMG 24372) and BOX-PCR cluster 2 strains (LMG $24367^{\mathrm{T}}$ and LMG 24368) 
to elucidate their taxonomic positions: the experiments were carried out with photobiotin-labelled probes in microplate wells, as described by Ezaki et al. (1989), using a HTS7000 Bio Assay Reader (Perkin Elmer) for the fluorescence measurements. The hybridization temperature was $45{ }^{\circ} \mathrm{C}$ and reciprocal reactions were performed for every pair of isolates. DNA-DNA hybridization values among representatives of the same BOX-PCR cluster were high $(76 \pm 5 \%$ and $95 \pm 5 \%$ for BOX-PCR cluster 1 and BOX-PCR cluster 2, respectively). The mean DNA-DNA hybridization value between a representative of BOXPCR cluster 1 and its phylogenetically closest neighbour, Ruegeria mobilis CIP $109181^{\mathrm{T}}$, was high $(87 \pm 3 \%)$, demonstrating that BOX-PCR cluster 1 isolates belong to Ruegeria mobilis (Wayne et al., 1987). On the other hand, the DNA-DNA hybridization values between BOX-PCR cluster 2 strain LMG $24367^{\mathrm{T}}$ and Ruegeria reference strains (Ruegeria atlantica LMG $23161^{\mathrm{T}}$, Ruegeria lacuscaerulensis LMG $23162^{\mathrm{T}}$, Ruegeria pomeroyi LMG $23168^{\mathrm{T}}$ and Ruegeria mobilis CIP $109181^{\mathrm{T}}$ ) were low (ranging from $8 \pm 6 \%$ to $30 \pm 2 \%$ ), indicating that BOX-PCR cluster 2 isolates represent a novel species within the genus Ruegeria.

The DNA G + C contents (mol\%) of strains LMG 24371 and LMG 24372 (BOX-PCR cluster 1) and of strains LMG $24367^{\mathrm{T}}$ and LMG 24368 (BOX-PCR cluster 2) were determined. DNA was enzymically degraded into nucleosides as described by Mesbah et al. (1989). The nucleoside mixture obtained was then separated using a Water Breeze HPLC system and an Xbridge Shield RP18 column thermostabilized at $37{ }^{\circ} \mathrm{C}$. The solvent used was $0.02 \mathrm{M} \mathrm{NH}_{4} \mathrm{H}_{2} \mathrm{PO}_{4}(\mathrm{pH} 4.0)$ with $1.5 \%$ acetonitrile. Non-methylated lambda phage (Sigma) and Escherichia coli LMG 2093 DNA were used as calibration reference and control, respectively. The DNA $\mathrm{G}+\mathrm{C}$ content for strains LMG 24371 and LMG 24372 (BOX-PCR cluster 1) was $59.0 \pm 0.5 \mathrm{~mol} \%$ and that for strains LMG $24367^{\mathrm{T}}$ and LMG 24368 (BOX-PCR cluster 2) was $61.0 \pm 0.4 \mathrm{~mol} \%$; both values are within the range for established species of the genus Ruegeria (González et al., 2003; Lee et al., 2007; Muramatsu et al., 2007; Petursdottir \& Kristjansson, 1997; Uchino et al., 1998).

Strains LMG 24371 and LMG 24372 (BOX-PCR cluster 1) and strains LMG $24367^{\mathrm{T}}$ and LMG 24368 (BOX-PCR cluster 2) were investigated with regard to various morphological, physiological and biochemical characteristics. Colony morphology was determined after 4 days incubation at $20{ }^{\circ} \mathrm{C}$ on MA. Cells were tested for their Gram reactions and their catalase and oxidase activities. Growth on nutrient agar (NA), trypticase soy agar (TSA), R2A and peptone/yeast extract/glucose agar (Tan \& Rüger, 1999) was determined. The optimal salinity was determined using R2A supplemented with $1-20 \% \mathrm{NaCl}$ and incubated for 2 weeks at $20{ }^{\circ} \mathrm{C}$. The optimal growth temperature was determined using MA incubated at $4-45{ }^{\circ} \mathrm{C}$ for 2 weeks. The effect of $\mathrm{pH}$ on growth was analysed using marine broth 2216 (Difco) at pH 5.0-10.0 (with increments of 0.5 $\mathrm{pH}$ units) incubated at $20{ }^{\circ} \mathrm{C}$ for 7 days.
Degradation of casein and chitin (Reichenbach \& Dworkin, 1981), DNA [using Difco DNA agar, containing 0.01\% toluidine blue (Merck)], starch and L-tyrosine (Barrow \& Feltham, 1993) was tested; reactions were read after 5 days incubation at $20{ }^{\circ} \mathrm{C}$. To determine their lipolytic activity, the isolates were inoculated on Sierra's medium and incubated for 10 days at $20{ }^{\circ} \mathrm{C}$ (Sierra, 1957).

Susceptibility to the following antibiotics (from Oxoid) was tested on MA plates by using the disc diffusion method: cefoxitin $(30 \mu \mathrm{g})$, gentamicin $(30 \mu \mathrm{g})$, erythromycin $(15 \mu \mathrm{g})$, streptomycin $(25 \mu \mathrm{g})$, tetracycline $(30 \mu \mathrm{g})$, vancomycin $(30 \mu \mathrm{g})$, trimethoprim $(1.25 \mu \mathrm{g})$ and clindamycin $(2 \mu \mathrm{g})$. Results were read after 5 days incubation at $20{ }^{\circ} \mathrm{C}$.

Biochemical characteristics covered by the commercial microtest galleries API ZYM and API 20NE were assessed according to the instructions of the manufacturer (bioMérieux). API ZYM was read after $4 \mathrm{~h}$ incubation at $20{ }^{\circ} \mathrm{C}$ and API $20 \mathrm{NE}$ was read after $48 \mathrm{~h}$ incubation at $20{ }^{\circ} \mathrm{C}$.

The cell morphologies of strains LMG 24371 (BOX-PCR cluster 1) and LMG $24367^{\mathrm{T}}$ (BOX-PCR cluster 2) were determined by means of transmission electron microscopy. Cells were negatively stained with $2 \%$ uranyl acetate. Ultrathin sections were prepared and analysed as described by Mast et al. (2005) (Fig. 3). Cells of LMG 24371 were found to be rod-shaped $(0.8 \times 1.4 \mu \mathrm{m})$ and flagellated (having single polar flagella). Poly- $\beta$-hydroxybutyrate inclusion bodies were observed for only a minority of cells.

The results of the phenotypic analysis are summarized in Table 1. Isolates in BOX-PCR cluster 2 could be easily distinguished from established Ruegeria species on the basis of their phenotypic features. We conclude that the BOXPCR cluster 2 isolates represent a novel species within the genus Ruegeria, for which the name Ruegeria scottomollicae sp. nov. is proposed. The BOX-PCR cluster 1 isolates were identified as belonging to the species Ruegeria mobilis.

\section{Description of Ruegeria scottomollicae sp. nov.}

Ruegeria scottomollicae (scot.to'mol.li.cae. N.L. gen. n. scottomollicae in honour of Dr Victoria Scotto-Mollica and Dr Alfonso Mollica, both of whom were pioneers in the field of microbe-induced corrosion of steels and the generation of electroactive seawater biofilms).

Cells are Gram-negative, ovoid rods $(1 \times 1.3 \mu \mathrm{m})$. Motile (each cell having two polar flagella). Long, slender, fibrillar extensions from the cell surface and poly- $\beta$-hydroxybutyrate inclusion bodies are observed (Fig. 3). Colonies are round, beige and $2 \mathrm{~mm}$ in diameter after 4 days incubation on MA at $20{ }^{\circ} \mathrm{C}$. Growth occurs after 2 days at $20{ }^{\circ} \mathrm{C}$ on MA and after 5 days on TSA. Weak growth occurs on R2A and NA. No growth occurs on peptone/yeast extract/ glucose agar. The temperature range for growth is $4-40{ }^{\circ} \mathrm{C}$; growth at $40{ }^{\circ} \mathrm{C}$ is weak. No growth occurs at or above $45{ }^{\circ} \mathrm{C}$. The $\mathrm{NaCl}$ range for growth is $1-15 \%$; no growth occurs at or above $16 \% \mathrm{NaCl}$. The $\mathrm{pH}$ range for growth is 5-9; the optimal pH for growth is 6.5-8.5. Exhibits catalase 


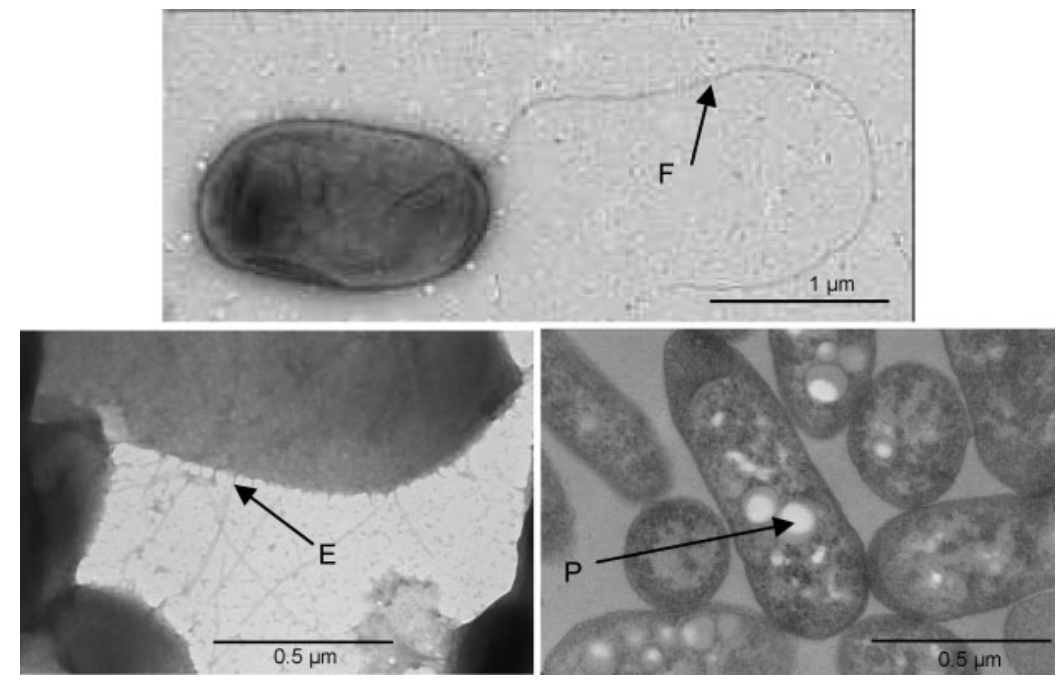

Fig. 3. Electron micrographs of LMG $24367^{\top}$, showing a polar flagellum (F), a poly- $\beta$-hydroxybutyrate inclusion body $(P)$ and fibrillar extensions (E).

and oxidase activities. Degrades tyrosine, Tween 80 and aesculin, but not DNA, starch, chitin, casein or gelatin. Activity is observed for leucine arylamidase, alkaline phosphatase, acid phosphatase, naphthol-AS-BI-phosphohydrolase and $N$-acetyl- $\beta$-glucosaminidase. Weak activity is detected for the following enzymes: esterase (C4), esterase lipase (C8), $\alpha$-galactosidase and $\alpha$-glucosidase. No activity is observed for valine arylamidase, $\beta$-glucuronidase, $\beta$-glucosidase, $\alpha$-mannosidase, lipase (C14), cystine arylamidase, trypsin, $\alpha$-chymotrypsin, arginine dihydrolase, urease, $\beta$ galactosidase or $\alpha$-fucosidase. Nitrate is not reduced to nitrite or to nitrogen. Indole is not produced and glucose is not fermented. The following are not assimilated: D-glucose, Larabinose, D-mannose, D-mannitol, $\mathrm{N}$-acetylglucosamine, maltose, potassium gluconate, capric acid, adipic acid, malate, citrate and phenylacetic acid. Susceptible to streptomycin $(25 \mu \mathrm{g})$ and cefoxitin $(30 \mu \mathrm{g})$, moderately susceptible to erythromycin $(15 \mu \mathrm{g})$ and gentamicin $(30 \mu \mathrm{g})$ and resistant to tetracycline $(30 \mu \mathrm{g})$, vancomycin $(30 \mu \mathrm{g})$, trimethoprim $(1.25 \mu \mathrm{g})$ and clindamycin $(2 \mu \mathrm{g})$. Major fatty acids are $\mathrm{C}_{10: 0} 3-\mathrm{OH}, 11$-methyl $\mathrm{C}_{18: 1} \omega 7 c, \mathrm{C}_{16: 0}, \mathrm{C}_{16: 0} 2$ $\mathrm{OH}, \mathrm{C}_{18: 1} 2-\mathrm{OH}, \mathrm{C}_{18: 1} \omega 7 c$ and an unknown fatty acid with an equivalent chain-length of 11.799. All other fatty acids detected are present in trace amounts. The DNA G $+\mathrm{C}$ content is $61.0 \pm 0.4 \mathrm{~mol} \%$.

The type strain, LMG $24367^{\mathrm{T}}\left(=\mathrm{CCUG} 55858^{\mathrm{T}}\right)$, was isolated from a marine, electroactive biofilm in Genoa, Italy. A second isolate with a different BOX-PCR profile is LMG 24368.

\section{Emended description of Ruegeria mobilis Muramatsu et al. 2007}

The description is as given by Muramatsu et al. (2007), but with the following additions. Susceptible to streptomycin $(25 \mu \mathrm{g})$ and cefoxitin $(30 \mu \mathrm{g})$, moderately susceptible to erythromycin $(15 \mu \mathrm{g})$ and resistant to trimethoprim $(1.25 \mu \mathrm{g})$, tetracycline $(30 \mu \mathrm{g})$, vancomycin $(30 \mu \mathrm{g})$, gentamicin $(10 \mu \mathrm{g})$ and clindamycin $(2 \mu \mathrm{g})$. Alkaline phosphatase activity and leucine arylamidase activity are observed. Weak acid phosphatase activity and weak naphthol-AS-BI-phosphohydrolase activity are observed. No activity is observed for the following: esterase (C4), esterase lipase (C8), lipase (C14), valine arylamidase, cystine arylamidase, trypsin, $\alpha$-chymotrypsin, $\alpha$-galactosidase, $\beta$ galactosidase, $\beta$-glucuronidase, $\beta$-glucosidase, $\alpha$-mannosidase and $\alpha$-fucosidase. Variable results are obtained for the hydrolysis of DNA and Tween 80 and for the activities of $\alpha$ glucosidase and $N$-acetyl- $\beta$-glucosaminidase.

\section{Emended description of Ruegeria lacuscaerulensis (Petursdottir and Kristjansson 1997) Yi et al. 2007}

The description is as given by Petursdottir \& Kristjansson (1997) and Yi et al. (2007), but with the following additions. Susceptible to cefoxitin $(30 \mu \mathrm{g})$, moderately susceptible to erythromycin $(15 \mu \mathrm{g})$ and resistant to vancomycin $(30 \mu \mathrm{g})$, trimethoprim $(1.25 \mu \mathrm{g})$, clindamycin $(2 \mu \mathrm{g})$ and gentamicin $(10 \mu \mathrm{g})$.

\section{Emended description of Ruegeria atlantica (Rüger and Höfle 1992) Uchino et al. 1999}

The description is as given by Rüger \& Höfle (1992), Uchino et al. (1998), Martens et al. (2006), Muramatsu et al. (2007) and Yi et al. (2007), but with the following additions. Susceptible to cefoxitin $(30 \mu \mathrm{g})$, vancomycin $(30 \mu \mathrm{g})$ and streptomycin $(25 \mu \mathrm{g})$, moderately susceptible to erythromycin $(15 \mu \mathrm{g})$ and resistant to trimethoprim $(1.25 \mu \mathrm{g})$, tetracycline $(30 \mu \mathrm{g})$, gentamicin $(10 \mu \mathrm{g})$ and clindamycin $(2 \mu \mathrm{g})$.

\section{Emended description of Ruegeria pomeroyi (González et al. 2003) Yi et al. 2007}

The description is as given by González et al. (2003) and Yi et al. (2007), but with the following additions. Susceptible 
Table 1. Summary of the results of phenotypic tests for strains LMG $24367^{\top}$ and LMG 24368 , BOX-PCR cluster 1 and established Ruegeria species

Taxa: 1, LMG 24367 ${ }^{\mathrm{T}}$ and LMG 24368 (Ruegeria scottomollicae sp. nov.); 2, LMG 24371 and LMG 24372 (representing BOX-PCR cluster 1); 3, Ruegeria atlantica (data from Rüger \& Höfle, 1992; Uchino et al., 1998; Martens et al., 2006; Muramatsu et al., 2007; Yi et al., 2007); 4, Ruegeria lacuscaerulensis LMG $23162^{\mathrm{T}}$ (Petursdottir \& Kristjansson, 1997; Yi et al., 2007); 5, Ruegeria pomeroyi LMG 23168 ${ }^{\mathrm{T}}$ (González et al., 2003; Yi et al., 2007); 6, Ruegeria mobilis (Muramatsu et al., 2007); 7, Ruegeria pelagia KCCM 42378 ${ }^{\mathrm{T}}$ (Lee et al., 2007). +, Positive reaction; -, negative reaction; $\mathrm{W}$, weakly positive reaction; $\mathrm{M}$, moderate susceptibility to an antibiotic; ND, no data available.

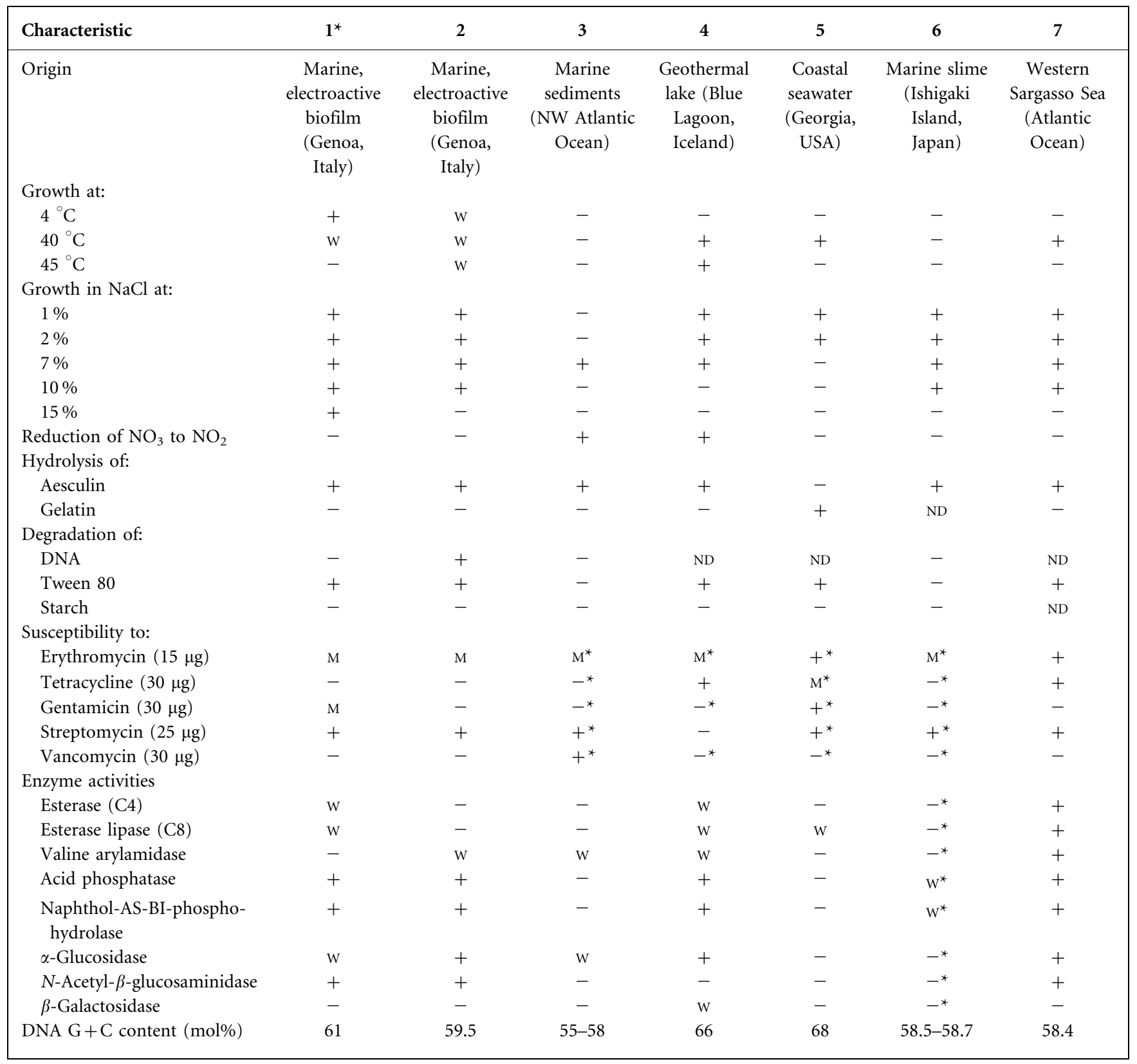

${ }^{*}$ Data from this study.

to cefoxitin $(30 \mu \mathrm{g})$, erythromycin $(15 \mu \mathrm{g})$, gentamicin $(10 \mu \mathrm{g})$ and streptomycin $(25 \mu \mathrm{g})$, moderately susceptible to tetracycline $(30 \mu \mathrm{g})$ and resistant to trimethoprim $(1.25 \mu \mathrm{g})$, vancomycin $(30 \mu \mathrm{g})$ and clindamycin $(2 \mu \mathrm{g})$.

\section{Acknowledgements}

This work is funded by the European Commission (EA BIOFILMS508866; NEST). The Fund for Scientific Research - Flanders (FWO Vlaanderen) is acknowledged for the financial support of P.V. 


\section{References}

Arahal, D. R., Macián, M. C., Garay, E. \& Pujalte, M. J. (2005). Thalassobius mediterraneus gen. nov., sp. nov., and reclassification of Ruegeria gelatinovorans as Thalassobius gelatinovorus comb. nov. Int $J$ Syst Evol Microbiol 55, 2371-2376.

Barrow, G. I. \& Feltham, R. K. A. (1993). Cowan and Steel's Manual for the Identification of Medical Bacteria, 3rd edn. Cambridge: Cambridge University Press.

Coenye, T., Falsen, E., Vancanneyt, M., Hoste, B., Govan, J. R., Kersters, K. \& Vandamme, P. (1999). Classification of Alcaligenes faecalis-like isolates from the environment and human clinical samples as Ralstonia gilardii sp. nov. Int J Syst Bacteriol 49, 405-413.

Edwards, U., Rogall, T., Blocker, H., Emde, M. \& Bottger, E. C. (1989). Isolation and direct complete nucleotide determination of entire genes. Characterization of a gene coding for $16 \mathrm{~S}$ ribosomal RNA. Nucleic Acids Res 17, 7843-7853.

Ezaki, T., Hashimoto, Y. \& Yabuuchi, E. (1989). Fluorometric deoxyribonucleic acid-deoxyribonucleic acid hybridization in microdilution wells as an alternative to membrane filter hybridization in which radioisotopes are used to determine genetic relatedness among bacterial strains. Int J Syst Bacteriol 39, 224-229.

Faimali, M., Chelossi, E., Garaventa, F., Corrà, C., Greco, G. \& Mollica, A. (2008). Evolution of oxygen reduction current and biofilm on stainless steels cathodically polarised in natural aerated seawater. Electrochim Acta 54, 148-153.

González, J. M., Covert, J. S., Whitman, W. B., Henriksen, J. R., Mayer, F., Scharf, B., Schmitt, R., Buchan, A., Fuhrman, J. A. \& other authors (2003). Silicibacter pomeroyi sp. nov. and Roseovarius nubinhibens sp. nov., dimethylsulfoniopropionate-demethylating bacteria from marine environments. Int J Syst Evol Microbiol 53, 1261-1269.

Hall, T. A. (1999). BioEdit: a user-friendly biological sequence alignment editor and analysis program for Windows 95/98/NT. Nucleic Acids Symp Ser 41, 95-98.

Lee, K., Choo, Y.-J., Giovannoni, S. J. \& Cho, J.-C. (2007). Ruegeria pelagia sp. nov., isolated from the Sargasso Sea, Atlantic Ocean. Int J Syst Evol Microbiol 57, 1815-1818.

Martens, T., Heidorn, T., Pukall, R., Simon, M., Tindall, B. J. \& Brinkhoff, T. (2006). Reclassification of Roseobacter gallaeciensis RuizPonte et al. 1998 as Phaeobacter gallaeciensis gen. nov., comb. nov., description of Phaeobacter inhibens sp. nov., reclassification of Ruegeria algicola (Lafay et al. 1995) Uchino et al. 1999 as Marinovum algicola gen. nov., comb. nov., and emended descriptions of the genera Roseobacter, Ruegeria and Leisingera. Int J Syst Evol Microbiol 56, 1293-1304.

Mast, J., Nanbru, C., Van Den Berg, T. \& Meulemans, G. (2005). Ultrastructural changes of the tracheal epithelium after vaccination of day-old chickens with the La Sota strain of Newcastle disease virus. Vet Pathol 42, 559-565.

Mergaert, J., Verhelst, A., Cnockaert, M. C., Tan, T. L. \& Swings, J. (2001). Characterization of facultative oligotrophic bacteria from polar seas by analysis of their fatty acids and $16 \mathrm{~S}$ rDNA sequences. Syst Appl Microbiol 24, 98-107.

Mesbah, M., Premachandran, U. \& Whitman, W. B. (1989). Precise measurement of the $\mathrm{G}+\mathrm{C}$ content of deoxyribonucleic acid by high-performance liquid chromatography. Int J Syst Bacteriol 39, 159-167.

Muramatsu, Y., Uchino, Y., Kasai, H., Suzuki, K. \& Nakagawa, Y. (2007). Ruegeria mobilis sp. nov., a member of the Alphaproteobacteria isolated in Japan and Palau. Int J Syst Evol Microbiol 57, 1304-1309.

Petursdottir, S. K. \& Kristjansson, J. K. (1997). Silicibacter lacuscaerulensis gen. nov., sp. nov., a mesophilic moderately halophilic bacterium characteristic of the Blue Lagoon geothermal lake in Iceland. Extremophiles 1, 94-99.

Pitcher, D. G., Saunders, N. A. \& Owen, R. J. (1989). Rapid extraction of bacterial genomic DNA with guanidium thiocyanate. Lett Appl Microbiol 8, 151-156.

Rademaker, J. L. W. \& De Bruijn, F. J. (1997). Characterization and classification of microbes by rep-PCR genomic fingerprinting and computer-assisted pattern analysis. In DNA Markers: Protocols, Applications, and Overviews, pp. 151-171. Edited by G. CaetanoAnollès \& P. M. Gresshoff. New York: Wiley.

Rademaker, J. L. W., Hoste, B., Louws, F. J., Kersters, K., Swings, J., Vauterin, L., Vauterin, P. \& De Bruijn, F. J. (2000). Comparison of AFLP and rep-PCR genomic fingerprinting with DNA-DNA homology studies: Xanthomonas as a model system. Int J Syst Evol Microbiol 50, 665-677.

Raes, J. \& Van De Peer, Y. (1999). ForCon: a software tool for the conversion of sequence alignments. (http://www.ebi.ac.uk/embnet. news/vol6_1/ForCon/body_forcon.html).

Reichenbach, H. \& Dworkin, M. (1981). Introduction to the gliding bacteria. In The Prokaryotes, vol. 1, pp. 315-327. Edited by M. P. Starr, H. Stolp, H. G. Trüper, A. Balows \& H. G. Schlegel. Berlin: Springer.

Rüger, H. J. \& Höfle, M. G. (1992). Marine star-shaped-aggregateforming bacteria: Agrobacterium atlanticum sp. nov.; Agrobacterium meteori sp. nov.; Agrobacterium ferrugineum sp. nov., nom. rev.; Agrobacterium gelatinovorum sp. nov., nom. rev.; and Agrobacterium stellulatum sp. nov., nom. rev. Int J Syst Bacteriol 42, 133-143.

Saitou, N. \& Nei, M. (1987). The neighbor-joining method: a new method for reconstructing phylogenetic trees. Mol Biol Evol 4, 406425.

Sierra, G. (1957). A simple method for the detection of lipolytic activity of microorganisms and some observations on the influence of the contact between cells and fatty substrates. Antonie van Leeuwenhoek 23, 15-22.

Stackebrandt, E. \& Ebers, J. (2006). Taxonomic parameters revisited: tarnished gold standards. Microbiol Today 33, 152-155.

Tan, T. L. \& Rüger, H. J. (1999). Enrichment, isolation, and Biolog metabolic fingerprints of oligotrophic bacteria from the Antarctic Ocean. Arch Hydrobiol Spec Issues 54, 255-272.

Thompson, J. D., Gibson, T. J., Plewniak, F., Jeanmougin, F. \& Higgins, D. G. (1997). The CLUSTAL_X windows interface: flexible strategies for multiple sequence alignment aided by quality analysis tools. Nucleic Acids Res 25, 4876-4882.

Uchino, Y., Hirata, A., Yokota, A. \& Sugiyama, J. (1998). Reclassification of marine Agrobacterium species: proposals of Stappia stellulata gen. nov., comb. nov., Stappia aggregata sp. nov., nom. rev., Ruegeria atlantica gen. nov., comb. nov., Ruegeria gelatinovora comb. nov., Ruegeria algicola comb. nov., and Ahrensia kieliense gen. nov., sp. nov., nom. rev. J Gen Appl Microbiol 44, 201-210.

Vandecandelaere, I., Nercessian, O., Segaert, E., Achouak, W., Mollica, A., Faimali, M., De Vos, P. \& Vandamme, P. (2008). Alteromonas genovensis sp. nov., isolated from a marine electroactive biofilm and emended description of Alteromonas macleodii Baumann et al. 1972 (Approved Lists 1980). Int J Syst Evol Microbiol 58, 25892596.

Van De Peer, Y. \& De Wachter, R. (1994). TREeCON for Windows: a software package for the construction and drawing of evolutionary trees for the Microsoft Windows environment. Comput Appl Biosci 10, 569-570.

Versalovic, J., Schneider, M., de Bruijn, F. J. \& Lupski, J. R. (1994). Genomic fingerprinting of bacteria using repetitive sequence-based polymerase chain reaction. Methods Mol Cell Biol 5, 25-40. 
Wayne, L. G., Brenner, D. J., Colwell, R. R., Grimont, P. A. D., Kandler, O., Krichevsky, M. I., Moore, L. H., Moore, W. E. C., Murray, R. G. E. \& other authors (1987). International Committee on Systematic Bacteriology. Report of the ad hoc committee on reconciliation of approaches to bacterial systematics. Int J Syst Bacteriol 37, 463-464.
Yi, H., Lim, Y. W. \& Chun, J. (2007). Taxonomic evaluation of the genera Ruegeria and Silicibacter: a proposal to transfer the genus Silicibacter Petursdottir and Kristjansson 1999 to the genus Ruegeria Uchino et al. 1999. Int J Syst Evol Microbiol 57, 815-819. 